\title{
Revisiting the Organisational Identification Assessment from a Managerial Perspective: A Case Study on a Romanian Public University
}

\section{Simona Mălăescu, Dan Chiribucă, Anamaria Bogdan, Sonia Pavlenko, Monica Petric, Adriana Șerban, Oana Tămaș}

\author{
Centre for University Strategy and Quality Management, \\ Babeș-Bolyai University, 1. M. Kogălniceanu St. Cluj-Napoca, Romania \\ simona.malaescu@ubbcluj.ro
}

\begin{abstract}
Although there is a large body of literature on organizational identification (OID), in recent years few of them have addressed the higher education context, mostly on student's identification and rarely on the identification of academic and research staff. Of these, their main focus is usually on different constructs, exploring OID in its role as mediator/moderator of these organizational issues and most often only one form of OID is acknowledged. The theoretical progress is evident, the essential necessity for large organizations to foster a sense of oneness in employees is acknowledged. However, from a managerial perspective, the issues of how many or which antecedents should be nurtured in this context in order to obtain results and the doubtful adaptability of considering just one form of OID are almost a decade old. This paper presents and discusses the results of a survey carried out on 1072 academics and researchers from Babes-Bolyai University, Romania. By assessing three forms of OID (OID, ambivalent identification and neutral identification) and certain relevant antecedents in the case of a large public university, the study addresses a gap in recent literature. Results are consistent with the Extended Model of Organizational Identification and strengthen the need to acknowledge the operational importance of ambivalent and neutral identification from a managerial perspective in the case of higher education employees. Theoretical contributions and practical implications of results are also discussed.
\end{abstract}

Keywords: organizational identification, human resources, higher education 
56• Journal of Research in Higher Education • Vol. I, No. 1, 2017

\section{Introduction}

In the first two decades of organisational identification litterature, researchers focused on its antecedents as well as the consequences of the employees' organisational identification, producing valuable insight for managers trying to make sense of and to manage better complex organizations and the manner in which these interact with their environment. Organisational identification (OID) has the potential of generating a series of positive results both at the level of the organization as well as the level of the individuals (He \& Brown, 2013), starting from a feeling of wellbeing and an increased employees' satisfaction at the job (Abrams \& De Moura, 2001; Yuan et al., 2016; Liu et al., 2016) up to a higher employee performance (Mael \& Ashforth, 1995; Bhattacharya et al., 1995; van Knippenberg, 2000; van Knippenberg \& van Schie, 2000; Riketta, 2005; Ashforth et al., 2008; Callea et al., 2016; Turen et al., 2017; Conroy et al., 2017) or in-role performance and organizational citizenship behaviors (Vinh Nhat Lu et al., 2017). Both task-specific performance (Hekman et al., 2016) as well as the overall performance at the workplace have been linked to OID (Walumbwa et al. 2008; Weiseke et al. 2008; Conroy et al., 2017).

The employees' creativity, seen as their capacity of generating original ideas meant to improve their tasks as well as their efficiency on the one hand, and the organisation's efficiency on the other (Amabile et al. 1996), has also been linked to OID (Hirst \& van Knippenberg, 2009; Madjar et al., 2011; Liu et al., 2016) - a natural process when the interests and wellbeing of the individual converge and identify with those of the organisation $\mathrm{s} / \mathrm{he}$ is part of, as a result of a greater creative effort (He \& Brown 2013).

One of the important mechanisms through which the creative effort mediates the impact of identification on creativity relies on the employees' willingness to put in a greater effort in improving their tasks and in making the organisation more efficient (Hirst et al. 2009; He \& Brown 2013).

Other behaviours and attitudes of the employees, that are relevant for the beneficial functioning of an organisation and which have been connected to OID have been represented by: the intention of remaining in the organisation on long-term, citizenship behaviour within the 
organisation (organisational behavioral citizenship - OBC)(Van Dick 2001; Wu et al., 2016; Bang Nguyen et al, 2016; Callea et al., 2016; Schun et al., 2016; Newman et al., 2016; Costa Neves Cavazotte et al., 2017; Vinh Nhat Lu et al. 2017), job turnover intentions (Cole \& Bruch, 2006; Tavares et al., 2016; Fallatah et al. 2017), proactive work behaviors of voice and taking charge (Klimchak et al. 2016), knowledge sharing and knowledge integration (Bao et al., 2017), team spirit (Riketta \& Van Dick 2005), in-role behaviour and extra-role behaviour (Ma et al., 2016; Lam et al., 2016; Tavares et al., 2016) up untill the unethical pro-organizational behavior (Chen et al., 2016; Kong, 2016). Moreover, the higher the organisational identification, the lower the employees' intention of leaving the organisation (Liu \& Ngo, 2017) as well as their actual leaving of the organisation (Abrams el al. 1998; Bartel 2001; Costa Neves Cavazotte et al., 2017), unethical behaviors, resistance to organizational change or interpersonal conflict (Conroy et al., 2017).

In a meta-analysis on OID, He \& Brown (2013) quote some of the few studies (especially due to the difficult access to data) which have highlighted the connection between OID of the employees and the organisations' financial performance (Homburg et al. 2009; Weiseke et al. 2008).

Recent studies massively concentrate the focus on studying OID as a mediator/moderator of the aforementioned outcomes or new ones (Table 1). The mediation relationship is usually confirmed. In several situations the impact of OID on the outcome variable is theoretised as being also mediated by another variable, for example the organizationbased self-esteem, job engagement, and felt obligation toward the organization on the impact on OCB (Wu et al., 2016), the personal identification with the leader on the impact of OID upon job turnover intentions (Fallatah et al, 2017), personal factors (morality, other identifications) on the impact of OID upon the negative behaviors and attitude such as unethical behaviors, resistance to organizational change, lower performance, interpersonal conflict, negative emotions, and reduced well-being (Conroy et al., 2017) or the moral disengagement upon the unethical pro-organizational behavior (Chen et al., 2016). 
58• Journal of Research in Higher Education • Vol. I, No. 1, 2017

Table 1. Studies exploring the organisational identification in the mediator or moderator role (2016-2017)

\begin{tabular}{|c|c|c|c|c|c|}
\hline $\begin{array}{l}\text { Outcome } \\
\text { Variable }\end{array}$ & $\begin{array}{l}\text { Role } \\
\text { of IOD }\end{array}$ & Predictor & Context & Authors & Result \\
\hline $\begin{array}{l}\text { Attachment } \\
\text { and turnover }\end{array}$ & MED & $\begin{array}{l}\text { change in } \\
\text { personal status, } \\
\text { organizational } \\
\text { valence }\end{array}$ & $\begin{array}{l}\text { corporate } \\
\text { merge }\end{array}$ & $\begin{array}{l}\text { Sung et al., } \\
2017\end{array}$ & confirmed \\
\hline $\begin{array}{l}\text { Employee job } \\
\text { crafting }\end{array}$ & MED & $\begin{array}{l}\text { transformational } \\
\text { leadership }\end{array}$ & corporate & $\begin{array}{l}\text { Wang et al., } \\
2017\end{array}$ & $\begin{array}{l}\text { Partialy } \\
\text { confirmed } \\
\text { (low IOD } \\
\text { emp.) }\end{array}$ \\
\hline $\begin{array}{l}\text { OCB, intention } \\
\text { to leave }\end{array}$ & & & $\begin{array}{l}\text { federal } \\
\text { public } \\
\text { institutions }\end{array}$ & $\begin{array}{l}\text { Costa Neves } \\
\text { Cavazotte } \\
\text { et al., } 2017\end{array}$ & confirmed \\
\hline $\begin{array}{l}\text { Financial } \\
\text { professionals' } \\
\text { loyalty }\end{array}$ & MED & ethical leadership & $\begin{array}{l}\text { Financial } \\
\text { (Taiwan) }\end{array}$ & $\begin{array}{l}\text { Tseng et al., } \\
2017\end{array}$ & $\begin{array}{l}\text { Significally } \\
\text { mediated }\end{array}$ \\
\hline $\begin{array}{l}\text { Employees' job } \\
\text { performance }\end{array}$ & MED & $\begin{array}{l}\text { perc. qual. of } \\
\text { organizationally } \\
\text { provided meal } \\
\text { serv. }\end{array}$ & $\begin{array}{l}\text { Private } \\
\text { security- } \\
\text { sector } \\
\text { (Turkey) }\end{array}$ & $\begin{array}{l}\text { Turen et al., } \\
2017\end{array}$ & $\begin{array}{l}\text { partial } \\
\text { mediating }\end{array}$ \\
\hline $\begin{array}{l}\text { Employees' } \\
\text { pro- } \\
\text { environmental } \\
\text { behaviour }\end{array}$ & MED & $\begin{array}{l}\text { Corporate Social } \\
\text { Responsibility } \\
\text { (CSR) }\end{array}$ & $\begin{array}{l}\text { private } \\
\text { employees }\end{array}$ & $\begin{array}{l}\text { Gkorezis \& } \\
\text { Petridou, } \\
2017\end{array}$ & Confirmed \\
\hline $\begin{array}{l}\text { Supportive CSR } \\
\text { outcomes }\end{array}$ & MED & CSR partnership & $\begin{array}{l}\text { Non profit } \\
\text { organisation } \\
s\end{array}$ & $\begin{array}{l}\text { Rim et al., } \\
2017\end{array}$ & \\
\hline $\begin{array}{l}\text { Employee } \\
\text { entitlement }\end{array}$ & MOD & & & $\begin{array}{l}\text { Klimchak et } \\
\text { al., } 2016\end{array}$ & $\begin{array}{l}\text { Significant } \\
\text { moderatio } \\
n\end{array}$ \\
\hline $\begin{array}{l}\text { In-role } \\
\text { performance } \\
\text { and } \\
\text { organizational }\end{array}$ & $\begin{array}{l}\text { MED } \\
\text { MOD }\end{array}$ & $\begin{array}{l}\text { psychological } \\
\text { contracts }\end{array}$ & $\begin{array}{l}\text { Frontline } \\
\text { triads in } \\
\text { hotels }\end{array}$ & $\begin{array}{l}\text { Vinh Nhat } \\
\text { Lu et al., } \\
2017\end{array}$ & $\begin{array}{l}\text { Partialy } \\
\text { mediated }\end{array}$ \\
\hline $\begin{array}{l}\text { Post negative } \\
\text { event and pro- } \\
\text { organiz. }\end{array}$ & MED & $\begin{array}{l}\text { impact of } \\
\text { negative event }\end{array}$ & $\begin{array}{l}\text { National } \\
\text { Colleg. } \\
\text { Athletic Ass. }\end{array}$ & $\begin{array}{l}\text { Zavyalova } \\
\text { et al., } 2016\end{array}$ & $\begin{array}{l}\text { High rep. } \\
\text { when low } \\
\text { IOD }\end{array}$ \\
\hline
\end{tabular}




\begin{tabular}{|c|c|c|c|c|c|}
\hline behavior & & & & & $\begin{array}{l}\text { negative } \\
\text { output }\end{array}$ \\
\hline $\begin{array}{l}\text { Emp. extra-role } \\
\text { behavior }\end{array}$ & MED & POS & $\begin{array}{l}\text { nurses } \\
\text { (China) }\end{array}$ & $\begin{array}{l}\text { Lam et al., } \\
2016\end{array}$ & confirmed \\
\hline $\begin{array}{l}\text { Citizenship } \\
\text { behavior }\end{array}$ & MED & $\begin{array}{l}\text { workplace } \\
\text { ostracism }\end{array}$ & China & $\begin{array}{l}\text { Wu et al., } \\
2016\end{array}$ & confirmed \\
\hline $\begin{array}{l}\text { Unethical pro- } \\
\text { organizational } \\
\text { behavior }\end{array}$ & $\begin{array}{l}\text { predic } \\
\text { tor }\end{array}$ & & $\begin{array}{l}\text { China and } \\
\text { the United } \\
\text { States }\end{array}$ & $\begin{array}{l}\text { Chen et al., } \\
2016\end{array}$ & confirmed \\
\hline $\begin{array}{l}\text { Willingness to } \\
\text { engage in OCB }\end{array}$ & MED & & $\begin{array}{l}\text { broad } \\
\text { spectrum }\end{array}$ & $\begin{array}{l}\text { Schun et al., } \\
2016\end{array}$ & significant \\
\hline $\begin{array}{l}\text { Nurses' silence } \\
\text { towards patient } \\
\text { safety }\end{array}$ & MED & $\begin{array}{l}\text { workplace } \\
\text { ostracism }\end{array}$ & $\begin{array}{l}\text { Nursing } \\
\text { (Ciprus) }\end{array}$ & $\begin{array}{l}\text { Gkorezis et } \\
\text { al., } 2016\end{array}$ & $\begin{array}{l}\text { partially } \\
\text { mediated }\end{array}$ \\
\hline $\begin{array}{l}\text { Proactive work } \\
\text { behaviors } \\
\text { (voice and } \\
\text { taking charge) }\end{array}$ & MOD & $\begin{array}{l}\text { employee } \\
\text { entitlement }\end{array}$ & & $\begin{array}{l}\text { Klimchak et } \\
\text { al., } 2016\end{array}$ & $\begin{array}{l}\text { significant } \\
\text { moderatio } \\
\mathrm{n}\end{array}$ \\
\hline $\begin{array}{l}\text { Unethical pro- } \\
\text { organizational } \\
\text { behavior }\end{array}$ & MED & $\begin{array}{l}\text { work passion, } \\
\text { POS }\end{array}$ & U.S. & Kong, 2016 & $\begin{array}{l}\text { IOD } \\
\text { mediates } \\
\text { only on low } \\
\text { mindfullne } \\
\text { ss }\end{array}$ \\
\hline $\begin{array}{l}\text { Knowledge } \\
\text { sharing/integra } \\
\text { tion }\end{array}$ & MED & trust & $\begin{array}{l}\text { Chinese } \\
\text { companies }\end{array}$ & $\begin{array}{l}\text { Bao et al., } \\
2017\end{array}$ & $\begin{array}{l}\text { Partially } \\
\text { mediated }\end{array}$ \\
\hline $\begin{array}{l}\text { Subordinate } \\
\text { affiliative } \\
\text { behaviors }\end{array}$ & MED & $\begin{array}{l}\text { self-sacrificial } \\
\text { leadership }\end{array}$ & China & $\begin{array}{l}\text { Li et al., } \\
2016\end{array}$ & Confirmed \\
\hline $\begin{array}{l}\text { In-role } \\
\text { behaviour and } \\
\text { extra-role } \\
\text { behaviour }\end{array}$ & MED & job security & $\begin{array}{l}\text { Chinese air } \\
\text { transportatio } \\
\text { n group }\end{array}$ & $\begin{array}{l}\text { Ma et al., } \\
2016\end{array}$ & $\begin{array}{l}\text { partially } \\
\text { mediated }\end{array}$ \\
\hline $\begin{array}{l}\text { Employees' } \\
\text { intrapreneurial } \\
\text { behaviors }\end{array}$ & MED & $\begin{array}{l}\text { authentic } \\
\text { leadership, }\end{array}$ & & $\begin{array}{l}\text { Edu } \\
\text { Valsania et } \\
\text { al., } 2016\end{array}$ & Confirmed \\
\hline ОСВ & MED & $\begin{array}{l}\text { socially } \\
\text { responsible HR } \\
\text { management }\end{array}$ & $\begin{array}{l}\text { employees- } \\
\text { supervisors } \\
\text { (China) }\end{array}$ & $\begin{array}{l}\text { Newman et } \\
\text { al., } 2016\end{array}$ & $\begin{array}{l}\text { fully } \\
\text { mediated } \\
\text { (employee- } \\
\text { oriented }\end{array}$ \\
\hline
\end{tabular}


60• Journal of Research in Higher Education • Vol. I, No. 1, 2017

\begin{tabular}{|c|c|c|c|c|c|}
\hline & & & & & HRM) \\
\hline Job satisfaction & MED & $\begin{array}{l}\text { high-performance } \\
\text { work systems }\end{array}$ & $\begin{array}{l}\text { Diff. level } \\
\text { entreprise } \\
\text { emp. }\end{array}$ & $\begin{array}{l}\text { Liu et al., } \\
2016\end{array}$ & $\begin{array}{l}\text { Partially } \\
\text { mediate }\end{array}$ \\
\hline $\begin{array}{l}\text { Voice and } \\
\text { negative } \\
\text { feedback } \\
\text { seeking } \\
\text { behavior }\end{array}$ & MED & $\begin{array}{l}\text { servant } \\
\text { leadership }\end{array}$ & $\begin{array}{l}\text { food } \\
\text { company } \\
\text { (Pakistan) }\end{array}$ & $\begin{array}{l}\text { Chughtai, } \\
2016\end{array}$ & $\begin{array}{l}\text { Partially } \\
\text { mediates }\end{array}$ \\
\hline $\begin{array}{l}\text { OCB, job } \\
\text { performance }\end{array}$ & MED & $\begin{array}{l}\text { qualitative job } \\
\text { insecurity }\end{array}$ & $\begin{array}{l}\text { Western } \\
\text { contex }\end{array}$ & $\begin{array}{l}\text { Callea et al., } \\
2016\end{array}$ & $\begin{array}{l}\text { completely } \\
\text { mediated }\end{array}$ \\
\hline Job satisfaction & $\begin{array}{l}\text { MOD } \\
\text { oderat } \\
\text { or of } \\
\text { the } \\
\text { impac } \\
\text { t of }\end{array}$ & $\begin{array}{l}\text { organizational } \\
\text { justice }\end{array}$ & & $\begin{array}{l}\text { Yuan et al., } \\
2016\end{array}$ & $\begin{array}{l}\text { Significantl } \\
\text { y in low } \\
\text { OID }\end{array}$ \\
\hline $\begin{array}{l}\text { Employee } \\
\text { creativity }\end{array}$ & MED & $\begin{array}{l}\text { leadership } \\
\text { Abusive } \\
\text { supervision }\end{array}$ & & $\begin{array}{l}\text { Liu et al., } \\
2016\end{array}$ & confirmed \\
\hline
\end{tabular}

Sometimes the interaction between IOD and its mediator, for example the perceived organisational climate (ethical/non-etical) on the moral decisions of employees, proved to be more relevant than the separate role (van Gils et al., 2017). Among the variables proved to moderate the influence of OID in recent studies were collectivism, power distance, and future orientation on the impact on citizenship behavior (Wu et al., 2016), expected psychological contract on OCB (Bang Nguyen et al, 2016), competitive interorganizational relations on the impact on unethical pro-organizational behavior (Chen et al., 2016), trauma on the impact on work-family conflict in the case of fire-fighters (Allen et al, 2016).

\section{Antecedents and forms of Organisational Identification}

Aiming the optimisation of organisational performance by improving the aforementioned aspects (and considering them as being connected as well to the organisational identification), a series of research studies 
in the field of organisational management addressed the factors that are the premises of OID. Recent studies made a wide range of connections (Table 1) between OID and other organisational or leadership characteristics, in some cases mediated or moderated as well, by other relevant variables.

Table 2. Antecedent variables of organisational identification and mediators/moderators under study in recent research (2016-1017)

\begin{tabular}{|c|c|c|c|}
\hline $\begin{array}{l}\text { Antecedent } \\
\text { variable }\end{array}$ & Moderator/mediator & Sample/context & Authors \\
\hline $\begin{array}{l}\text { interpersonal and } \\
\text { informational } \\
\text { justice }\end{array}$ & $\begin{array}{l}\text { psychological contract } \\
\text { fulfillment, different levels } \\
\text { of equity sensitivity }\end{array}$ & $\begin{array}{l}\text { Comercial banks } \\
\text { employees (emp.) }\end{array}$ & $\begin{array}{l}\text { Asadullah et } \\
\text { al, } 2017\end{array}$ \\
\hline $\begin{array}{l}\text { internal and } \\
\text { external } \\
\text { corporate social } \\
\text { responsibility }\end{array}$ & $\begin{array}{l}\text { social and cultural } \\
\text { orientations }\end{array}$ & $\begin{array}{l}\text { fast-moving } \\
\text { consumer goods } \\
\text { conglomerate emp. }\end{array}$ & $\begin{array}{l}\text { Farooq et al., } \\
2017\end{array}$ \\
\hline $\begin{array}{l}\text { organizational } \\
\text { valence } \\
\text { change in } \\
\text { personal status }\end{array}$ & personal valence & Corporate context & $\begin{array}{l}\text { Sung et al., } \\
2017\end{array}$ \\
\hline $\begin{array}{l}\text { injunctive logics } \\
\text { (pre-entry } \\
\text { beliefs), } \\
\text { descriptive logics } \\
\text { (actual } \\
\text { experience) }\end{array}$ & & $\begin{array}{l}\text { healthcare context } \\
\text { (newcomers) }\end{array}$ & $\begin{array}{l}\text { Smith et al., } \\
2017\end{array}$ \\
\hline $\begin{array}{l}\text { authentic } \\
\text { leadership }\end{array}$ & $\begin{array}{l}\text { personal identification with } \\
\text { the leader }\end{array}$ & $\begin{array}{l}\text { Nursing } \\
\text { (newcomers) }\end{array}$ & $\begin{array}{l}\text { Fallatah et } \\
\text { al., } 2017\end{array}$ \\
\hline $\begin{array}{l}\text { corporate social } \\
\text { responsibility } \\
\text { (CSR) }\end{array}$ & employee engagement & $\begin{array}{l}\text { information } \\
\text { technology emp. } \\
\text { (Assia) }\end{array}$ & Gupta, 2017 \\
\hline $\begin{array}{l}\text { gender role } \\
\text { orientation and } \\
\text { career/family } \\
\text { role salience }\end{array}$ & & $\begin{array}{l}\text { three (large) } \\
\text { companies in China }\end{array}$ & $\begin{array}{l}\text { Liu \& Ngo, } \\
2017\end{array}$ \\
\hline $\begin{array}{l}\text { foreign } \\
\text { ownership and } \\
\text { foreign parent's }\end{array}$ & & $\begin{array}{l}\text { Korean managers } \\
\text { (multinational } \\
\text { corporations) }\end{array}$ & $\begin{array}{l}\text { Lee et al., } \\
2017\end{array}$ \\
\hline
\end{tabular}


62• Journal of Research in Higher Education • Vol. I, No. 1, 2017

\begin{tabular}{|l|l|l|l|}
\hline control & & & \\
\hline $\begin{array}{l}\text { internal and } \\
\text { external CSR }\end{array}$ & $\begin{array}{l}\text { Mediator (MED): perceived } \\
\text { external prestige and } \\
\text { perceived internal respect; } \\
\text { Moderator (MOD): calling } \\
\text { orientation }\end{array}$ & $\begin{array}{l}\text { (Large) } \\
\text { multinationals } \\
\text { (Pakistan) }\end{array}$ & $\begin{array}{l}\text { Hameed et } \\
\text { al., 2016 }\end{array}$ \\
\hline $\begin{array}{l}\text { authentic } \\
\text { leadership }\end{array}$ & MED: Cynicism & $\begin{array}{l}\text { white collar } \\
\text { employees }\end{array}$ & Kurt, 2016 \\
\hline POS & $\begin{array}{l}\text { OID MED along with } \\
\text { affective commitment } \\
\text { MOD: collectivism }\end{array}$ & Nurses (China) & $\begin{array}{l}\text { Lam et al., } \\
2016\end{array}$ \\
\hline $\begin{array}{l}\text { work passion } \\
\text { (obsessive } \\
\text { passion), POS }\end{array}$ & $\begin{array}{l}\text { MED: trait indfulness } \\
\text { MED IOD of antecedents on } \\
\text { unethical pro-org.behavior }\end{array}$ & U.S. & Kong, 2016 \\
\hline perceived CSR & $\begin{array}{l}\text { MED (succesive) Interacts } \\
\text { with overall justice through } \\
\text { the successive mediation of } \\
\text { perceived external prestige } \\
\text { and organizational pride }\end{array}$ & international utility \\
company & $\begin{array}{l}\text { De Roeck et } \\
\text { al., 2016 }\end{array}$ \\
\hline Age & $\begin{array}{l}\text { MED: employee's internal } \\
\text { motivation }\end{array}$ & $\begin{array}{l}\text { restaurant industry } \\
\text { (Taiwan) }\end{array}$ & $\begin{array}{l}\text { Lu et al., } \\
2016\end{array}$ \\
\hline CSR & $\begin{array}{l}\text { MED: meaningful work } \\
\text { MOD: ethical leadership }\end{array}$ & $\begin{array}{l}\text { Aviation company } \\
\text { emp. (Turkey) }\end{array}$ & $\begin{array}{l}\text { Akdogan et } \\
\text { al., 2016 }\end{array}$ \\
\hline CRS & professional sports & $\begin{array}{l}\text { Bergmann et } \\
\text { al., 2016 }\end{array}$ \\
\hline
\end{tabular}

Apart from the work of The Expanded model of Organisational Identification`s authors (Kreiner \& Ashforth, 2004; Ashforth, 2008) few studies acknowledged the existence of more than one way for the employees of identifying themselves with the organisation they work for. Along with Carlin et al. (2010) revalidating on a different context the initial extended model proposed by Kreiner and Ashfort (2004), Hoyer (2016) revealed the (not so negative) role of ambiguous organisational identification, Schuh et al. (2016) explored the antecedents and consequences of ambivalent identification and OID, and Humphreys \& Brown (2002) on their early work, enhanced the evidence on two of Elsbach (1999) forms dis-identification and neutral identification, and also schizo-identification (Humphreys \& Brown, 2002, p. 421) the last study being the only study undertook on a higher education context. 
This scarce preoccupation of assessing more than one form of OID in recent overwhelming literature is surprising considering the complexity and the equivocal character of some organisations (a situation which applies to comprehensive universities), the autonomy of the personnel and the flexible and dynamic character of the aims, values and beliefs of the individuals that characterise today's society.

Early researchers have noticed the situation in which the employees, at the same time, identify with certain aspects, values or practices of the organisation they work for and they disidentify with others (Kreiner \& Ashfort 2004; Dukerich et al. 1998; Elsbach 1999; Ashfort 2001), a situation for which they introduced the term ambivalent identification (AID) (or conflictual identification) (Kreiner \& Ashfort, 2004, p. 4). Kreiner \& Ashfort (2004) consider that the organisations in which this type of identification lacks are rather rare, and also think that the vision that disconsiders it would be a rather reductionist one.

In the organisations where the employees have ambivalent identification, the main drawback is the fact that they show reserves in exceeding the requested level of professional performance and consume cognitive and emotional resources which otherwise could be channelled towards supporting more productive organisational objectives. While the components of ambivalence that reflect positive associations are encouraged by the majority of the organisations, the negative ones are discourages, "this mixed message cand create isolation and stress for the ambivalent individual as well as perceptions of hypocrisy and pressure to conform" (Meyerson \& Scully 1995 in Kreiner \& Ashfort 2004, p. 4).

Research has also shown the situation in which, in the case of an employee, there lacks explicitly both the attachment or the perception of a congruence or identification with the defining elements of the employing organisation, as well as an explicit incongruence or incompatibility with its defining values. In short: a lack of both identification as well as disidentification of the employee with the organisation they work for, a situation designated by Elsbach (1999) as neutral identification (NID).

The employees who are in such a situation can define themselves cognitively in personal terms (as being, for example "singular": or "independent" or "autonomous": "I'm a loner; I'm my own person"); 
avoiding consciously the extremes of the attachment (either positive or negative) towards the organisation, as a result of previous experiences with the organisation they have worked for, or of the leadership styles they have experienced ("I don't take sides, I just do my job") (Kreiner \& Ashfort 2004, p. 5).

In the view of the authors of this study, this explicit absence of identification or disidentification is the self-definition of an employee represents a "suboptimal state; an employee defining him or herself as neutral towards the organisation (and its goals, values, mission) is less likely to feel engaged in and contribute to the organisation that one who does, particularly via extra role behaviors (Kreiner \& Ashforth 2004, p. 5).

Considering the practical value of the evidence like Kreiner and Ashforth`s findings that a positive reputation of the organisation can forestall disidentification and possibly AID, and an internally congruent organisational identity can forestall ambivalence and possibly neutrality or the fact that OID and AID interactively influence employees' willingness to engage in organizational citizenship behaviour but this impact is significantly reduced when employees experience AID (Schuh et al., 2016) we argue for the imperious necessity to assess two other forms (AID and NID) of employees (especially in the situation of higher education staff) manners to positions themselves at what their employer organisation values and stands for. This approach, along with selecting the most relevant antecedents for the particular context universities operates on in order to obtain accurate and relevant informations stood at the basis of the present research endeavour.

The literature review (see also Table 1-2) reveals that few studies were carried on higher education contexts and the majority of them on students OID or alumni (Zavyalova et al., 2016) and very few on staff and mostly qualitative in nature (Puusa \& Kekale, 2015; Humphreys \& Brown, 2002).

In all studies what stands out, comparing with the studies on other contexts (table 1 and 2), are the acknowledged importance and impact of IOD more than other processes (like social identification) over student commitment, achievement and satisfaction (Wilkins et al., 2016) and the choice of antecedents under study: some of them were university (organisation`s) characteristics, like the construed external image of the university (Myers et al., 2016), university brand 
personality, university brand knowledge, and university brand prestige (Balaji et al., 2016), other were individual`s reaction variables inspired by the organisation like satisfaction and trust in the university (Myers et al., 2016) or finally, environmental characteristics like perceived interorganizational competition (Myers et al., 2016). OID was found a strong predictor of student satisfaction (Wilkins et al., 2016) and strongly related with university-supportive behaviours such as university affiliation, suggestions for improvement, advocacy intentions, and participation in future activities (Balaji et al., 2016) including intended future involvement (Myers et al., 2016). Also students who identify with their university perceive their destiny as interweaved with the university which drives their desire to engage in university supportive behaviors (Balaji et al., 2016). Although OID was a strong predictor of satisfaction, student commitment was better at explaining student achievement (Wilkins et al., 2016).

Except for the evident and dominant focus on CSR (as an indirect and singular) measure of what the employees`organisations value and stand for, the majority of recent literature on other organisational contexts, apart from assessing a unique form of OID, don`t cover much of the relevant antecedents which usually determine the actual identification/ dezidentification process of the employee. Schuh et al. (2016) however, shown that employees' promotion and prevention focus form differential relationships with organizational identification and ambivalent identification, providing first evidence for a link between employees' regulatory focus and the dynamics of identification. A particular attention registered the perceived organisational support.

The employees perceiving their hiring organisation as being concerned with their wellbeing are more likely to offer, in their turn, investing psychologically in the organisation and developing a feeling of attachment and identification towards the organisation itself (Eisenberger et al. 2001). Edwards \& Peccei (2010) stress the fact that the perceived organisational support may contribute to the fulfilment of important socio-emotional needs of the employees, such as positive self-esteem, approval or affiliation need (Lee \& Peccei, 2007), which can intensify the identification and the emotional attachment to the organisation (Sung et al., 2017), leading to incorporating their member 
quality and their role status into their social identity (Rhoades \& Eisenberger 2002).

The recent reminder of the importance of assessing the organisational values broth by Myers et al. (2016) stressing that students' identification with their university reflects value congruence with the institution, satisfaction and trust, points out the necessity to revisit the basic key elements (organisational values and mission) in the approach of assessing and rising OID in universities, considering their core mission. The employees' OID is present when they define themselves at least partially by using elements that describe what the organisation represents and supports (mission, vision, etc.) (Kreiner \& Ashforth, 2004) or when they perceive that they form a unit together with the organisation and feel that they belong to it (Ashforth \& Mael 1989).

This conceptualisation of organisational identification relies on the social identity perspective, where one individual's social identity consists in being aware of the status of a member of a social group, together with the values and the emotional significance attached to this member status (Tajfel 1978) and thus, the organisation they work for may constitute that social category which the employee can later identify with (Ashforth \& Mael 1989; Haslam 2004).Taking into account the complexity of the organisational environment offered by the universities to their employees, of the latter's individuality and autonomy, in the attempt to offer an image of the level of identification of a large public university' employees, in this study we chose an extended theoretical model of identification (Kreiner \& Ashfort 2004).

Babeș-Bolyai University (BBU) is a public comprehensive university of advanced research and education, the largest Romanian university in terms of student numbers and consists of 21 faculties (organized into 94 teaching departments) and over 40 research units. In various rankings, $\mathrm{BBU}$ is ranked among the best universities in Romania and has a comparable performance with other similar universities from the region (Eastern and Central Europe), in 2016, in a metaranking of the Romanian Ministry of Education, BBU was ranked as the best Romanian university. One defining characteristic of BBU is its multiculturality mirroring the multi-ethnic tradition of the geographical region for which provides academic training: it has three lines of study, e.g. Romanian, Hungarian and German, that allow a complete university 
route (from bachelor to doctorate) to be completed in the chosen language (apart from study programmes in international languages, such as English, French, etc.)

Of the organisational antecedents selected in the initial model, in the case of a comprehensive university, based on previous research results, we considered necessary to evaluate mainly the organisational and individual antecedents and less those connected to the position that the employees hold. From the point of view of the generated directions for action, we considered useful apartart from key organisational characteristics like the organisational identity strength(OIS) (Kreiner \& Ashforth 2004; Puusa et al., 2015) and the organizational identity incongruence (OIDI) (Kreiner \& Ashforth, 2004), individual variable relevant for this profession as the need for organisational identification (NDOID) (Glynn 1998, Kreiner \& Ashforth, 2004) or the professional commitment (Blau 1989; Van Mannan \& Barley 1984; Caza \& Creary 2016) and individual characteristics.

A strong organisational identity is defined as being widely shared and deeply respected by its members (Kreiner \& Ashforth 2004). Organisations with a strong organisational identity offer a clear point of reference regarding their organisational identity ("This is who we are"), allowing their employees to decide whether the organisation fits their needs and wished, and attracting the potential employees who resonate with its mission and values (Ashforth \& Mael 1996; Kreiner \& Ashforth 2004). The strength or force of organisational identification is thus considered to be a consistent antecedent for the members' organisational identification. According to the positive or negative value of the identification, this indicator can be also an antecedent of disidentification, as the force of identification intensifies, as the case may be, the association or dissociation with the organisation's image.

The organizational identity incongruence was conceptualized as the situation in which an organisation send contradictory or mixed messages to its stakeholders in connection to what it is that it supports (which are the aspects that are important for the organisation) and their argumentation.

The organisations may develop multiple or hybrid identities, which could evolve into contradictory situations, especially in the situations in which the organisations are confronted with contradictory requirements from the environment they operate in (such as the need 
for a high performance and cost reduction), of the key stakeholders or are in a state of flux (Kreiner \& Ashforth 2004). Mainly, an identity incongruence represents the premises for forming the AID. Taking into consideration the reduced added value from a practical perspective of the information potentially yielded by the added evaluation of the fourth form of identification proposed by the extended model disidentification in comparison to the evaluation of the other three identification forms for the case of a university (such as predicting employee mobility, predicting the leaving of the organisation by these employees, etc.) we opted for restricting the instrument to the three already mentioned forms of organisational identification. Evaluating the manner in which, at the level of BBU, employees perceive the force of organisational identity and the level of organisational incongruence represents an objective of interest in itself, independent from the role it might play in the formation of another type of organisational identification.

The need for organisational identification can be described as being the members' predisposition for identifying with the organisation they are part of. Even though all individuals belonging to an organisation are somewhat receptive to identifying with it (as part of defining the self and of belonging), the levels at which they do it depend on how willing they are to be imprinted (Glynn 1998, p. 234) by the organisation (Glynn 1998; Kreiner \& Ashforth 2004). Professional commitment is defined, when it is conceptualised as a uni-dimensional construct, as the belief and acceptance by an individual of the values lying at the basis of its occupation and the wish to maintain the status of the member of that profession (Vandenberg \& Scarpello 1994). Individuals can build a social identity defined by their professional role, relying on aspect taken from their profession or from their organisation (Van Mannan \& Barley 1984; Caza \& Creary 2016).

Considering the need for quantitative research and empirical new evidence in the context of higher education institutions' staff identified, this study aims to assess the level and forms of organisational identification of the teaching and research personnel of a large public university as well as the main variable underpinning their crystallisation in the national context in which the university is operating. 
This diagnosis, as well as the operational information connected to the main directions of action aimed at stimulating the employees' organisational identification, as a lever for stimulating the set of elements that this has been connected with serve the main purpose of understanding and of improving the complex manner in which the university, as an organisation, functions and especially achieves performance. We expect that AID and NID, in the case of a higher education institution`s personnel will represent a significant manner to position themselves in respect of their employing organisation and that each of the forms will have different salient antecedents. We also expect that the organisational characteristics selected as antecedents will be also significantly connected with employees satisfaction with the university and its organisational values.

\section{Methodology}

Evaluating the level of OID was carried out through an survey based on a pen-and-paper questionnaire, applied to the entire teaching and research staff. The response rate at the level of the 21 faculties of the university varied: 15 faculties has response rates of over $50 \%$.

Participants. A number of 1072 academics and researchers responded to our survey, in the resulted sample the most important quota, for each academic ranks, matched the quota in the general population. The main descriptive data of the sample of participants and the comparison to the general population at the level of the university are shown in Table 3.

Instruments In order to evaluate the level of organisational identification, we opted for the instrument built by Kreiner \& Ashforth (2004), namely the Organisational Identification Measure, considered to be a much more comprehensive instrument for the nature and the strength of the attachment between the employee and the employer (Carlin et al. 2010). Consequently, most studies published in the field use sub-scales or compare themselves one way or another to the model, and the instrument, respectively, used by the afore-mentioned authors. From the instrument used by the authors in their 2004 study, we used the following subscales: Ambivalent Identification, Neutral 
Identification, Need for Identification, Organisational Identity Incongruence, Organisational Identity Strength for validating the initial model, and the Organisational Identification refined by Mael \& Ashforth (Mael 1988 unpublished; Mael \& Ashforth 1992). In order to measure the other antecedent variables and the consequences considered relevant for the context of higher education, we used: Professional Commitment (Blau 1989) for its unidimensional conceptualisation of the engagement towards profession and an item adapted among those suggested by Lockwood et al. (2002) for evaluating values such as promoting organisational success / avoiding organisational failure ("In this university, achieving performance is more important than avoiding/preventing failure").

All the items of the instrument of all sub-scales required that the subject rate on a Likert scale in five points to what extent the statements described various manners of relating to the organisation, to their profession, correspond to their situation. Another four items were suggested by the team who carried out this research for the arguments mentioned above for each individual dimension. Two of the items were represented by "In this university the individual initiatives are supported (individualism)"; "In this university the collective interest matters more than the individual interest (collectivism)" and used the same response scale as the other items. A third one represented a scale of "Very pleased - Very displeased" for measuring the satisfaction with the organisation. A fourth item, which was an adaptation of the identification graphic scale was used to evaluate the level of overlapping perceived by what on the one hand the organisation represents and what it supports in its entirety (BBU in this case) and, on the other hand, the nucleus department the investigating individual is a member of.

\begin{tabular}{|c|c|c|c|c|c|c|c|c|c|c|}
\hline & \multicolumn{2}{|c|}{$\begin{array}{l}\text { Teaching } \\
\text { staff } \\
\text { (primary) }\end{array}$} & \multicolumn{2}{|c|}{ Gender } & \multicolumn{2}{|c|}{$\begin{array}{l}\text { Research } \\
\text { Staff (exc.) }\end{array}$} & \multicolumn{4}{|c|}{$\begin{array}{l}\text { Academic rank (from } \\
\text { total UBB \%) }\end{array}$} \\
\hline & Indiv. & $\%$ & M\% & $\mathrm{F} \%$ & Indiv. & $\%$ & TA & $\mathrm{L}$ & AP & $\mathrm{P}$ \\
\hline $\begin{array}{l}\text { BBU General } \\
\text { population }\end{array}$ & 1472 & 83,6 & 50 & 50 & 290 & 16,4 & 9,25 & 36,42 & 25 & 12,8 \\
\hline IOD sample & 858 & 80,1 & 72(d) & 289 (d) & 214 & 19,9 & 45,3 & & 34,1 & \\
\hline
\end{tabular}

Table 3. Descriptive demografic of the sample and general population of research and teaching staff of $B B U$ 
Of the consequences of organisational identification, we considered relevant for this research the satisfaction with the organisation and organisational values, such as promoting organisational success/preventing organisational failure (Lockwood et al. 2002) (the latter being previously highlighted as potential moderators of the impact of organisational identification on other result variables). Lockwood et all (2002) highlight especially the idea that Eastern societies, that are more collectivist from a cultural point of view, tend to manifest stronger and more independent self-constructs, focusing on themselves as part of a network of interpersonal relationships (Heine et al 1999).

Thus, their members are more motivated to adapt to a group and to maintain social harmony, tending to focus on tasks and responsibilities towards others and to avoid behaviours leading to disruptions or to disappointing of significant people (Markus \& Kitayama, 1991; Triandis 1989; Lockwood et al. 2002).In the initial model, individualism was conceptualised as a premises for the neutral identification and assessed the employees' propensity towards placing personal aims above the collective ones (Triandis et al. 1986), by contrast with the subordination of personal aims to the collective good, specific to collectivism. In this research, by measuring the cognitive schemes of individualism and of collectivism, respectively, we were rather interested in exploring how the employees use these schemes in understanding the academic environment and the probability that a majority of individuals would behave in a manner congruent with the individualist or collectivist values, norms, beliefs and assumptions, in context that are significant for the academic behaviour.

\section{Results and Discussion}

The analysis carried out at the level of the entire sample revealed a high level of BBU employees' identification with the organisation they are part of, in which over $75 \%$ of the employees included in the investigation present an absolute above average level of identification (Sample average - 21, of a maximum of 30) (Figure 1). OID represents at the same time the dominant form of relating for $70 \%$ of the BBU employees to what the university represents and supports (its mission, 
vision, etc.) and perceive themselves as belonging, and as forming, respectively, a unit with the organisation they work for. $22 \%$ of the teaching and research staff of the university relates in an ambivalent manner to the organisation they are part of fact which seems a natural occurrence in today's context and given the higher level of individual autonomy that is specific for the employees of higher education institutions.

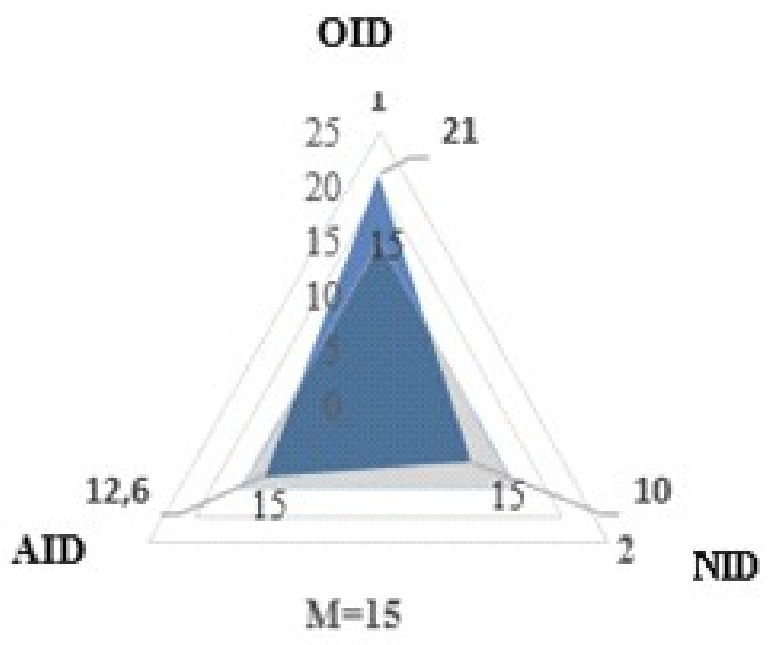

Figure 1. Organisational Identification of UBB teaching and research personnel

Given some antagonistic requirements and constraints that universities have to face and the distancing of the majority of the organisations from the univocal relating of their employees, the fact that a quarter of its staff manifest an ambivalent identification to the employer university just enhance the importance in acknowledging the existence of this form of positioning in the case of universities. Another $5 \%$ of the investigated staff presents as their dominant characteristic a form of neutral identification in relation to the university, while in the case of the remaining 3\% there could not be identified a dominant manner of relation, mainly due to the reduced rate of response to those items. 


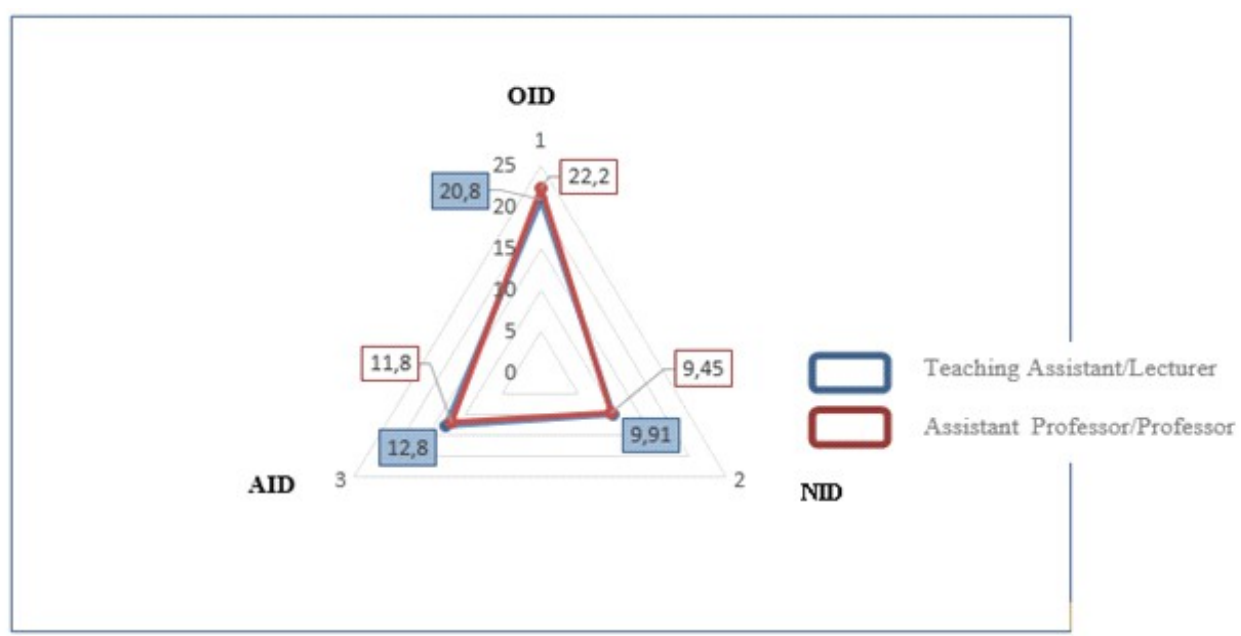

Figure 2. Organisational Identification of UBB teaching personnel (mean scores of each identification form in teaching subpopulation)

Among the teaching staff, the percentage of OID as a dominant form of employees' relating to the organisation they are part of grows up to $74 \%$, given the lower percentage $(18 \%)$ in comparison with the percentage at the level of the entire sample, of the academics who show an AID with the elements supported by the organisation they are part of.

The analysis of academic ranks (Figure 2) revealed that among the academics that hold the positions of Associate Professor and Professor there is a higher level of OID ( $\mathrm{M}=22.2$ - the highest value of all analysed sub-populations) in comparison to those holding the positions of Assistant Lecturer and Lecturer, which show the lowest average value of all the categories analysed (20.8). Among the female staff who hold the higher academic positions, the average of organisational identification decreases slightly $(M=21.95)$ in comparison to the male population from those particular academic ranks, differing from the female segment on the academic ranks of assistant lecturer and lecturer where a higher level of organisational identification is recorded $(\mathrm{M}=$ 21.2) than for the male population.

The AID forms record the highest average among the staff in the positions of assistant lecturer and lecturer, respectively $(M=12.8)$ and is higher when taking into consideration only the results of the female 
staff at this academic level $(M=13.1)$. Again, among the female staff holding the positions of Associate Professor and Professor the averages were lower $(\mathrm{M}=11.6)$. The NID at the level of both higher and lower academic positions recoded rather close values and near the averages of the entire sample - the lowest value being recorded again among females staff on higher academic positions $(M=9.11)$. In the analysis carried out on the teaching staff taking into consideration the lines of study, the data revealed a slightly highly level of OID in the case of the 172 academics surveyed who declared to be working for the Hungarian line of study $(\mathrm{M}=21.8)$, followed by the Romanian line of study. The AID form also records a higher average and sensibly equal among the academics of the Hungarian and Romanian lines of study. 
Table 4. Correlation matrix of variables connected with the forms of OID in BBU

\begin{tabular}{|l|l|l|l|l|l|l|l|l|l|l|l|}
\hline Variable & OID & NID & AID & OIS & OIDI & NDOID & Prof.C & Indiv. & Coll. & VAI & Satisf \\
\hline OID & & $-0,392$ & $-0,233$ & 0,471 & $-0,323$ & 0,591 & 0,431 & 0,399 & 0,170 & 0,329 & 0,411 \\
\hline NID & & & 0,442 & $-0,294$ & 0,382 & $-0,394$ & $-0,527$ & $-0,267$ & $-0,143$ & $-0,211$ & $-0,333$ \\
\hline AID & & & & $-0,478$ & 0,634 & $-0,170$ & $-0,417$ & $-0,417$ & $-0,482$ & $-0,174$ & $-0,567$ \\
\hline OIS & & & & & $-0,650$ & 0,299 & 0,322 & 0,554 & 0,276 & 0,354 & 0,612 \\
\hline OIDI & & & & & & $-0,243$ & $-0,379$ & $-0,490$ & $-0,262$ & 0,330 & $-0,572$ \\
\hline NDOID & & & & & & & 0,301 & 0,237 & 0,141 & 0,193 & 0,253 \\
\hline Prof.C & & & & & & & & 0,346 & 0,094 & 0,207 & 0,385 \\
\hline Ind. & & & & & & & & & 0,210 & 0,347 & 0,525 \\
\hline Coll. & & & & & & & & & & 0,342 & 0,202 \\
\hline VAI & & & & & & & & & & & 0,356 \\
\hline Satisf & & & & & & & & & & & $0,63 *$ \\
\hline
\end{tabular}

All correlations are significant at the 0,01 level unless specified otherwise

* The correlation is significant at the 0,05 level.

$\mathrm{n}$ The correlation is not significant 
The correlational analysis revealed that of the forms of identification, at the level of academics, the most significant relation with satisfaction manifested towards the organisation was register by AID, which correlated the strongest and negatively (-.57) with the employees' satisfaction towards the organisation they are part of (Table 4), followed by the positive correlation with organisational identification (.42) and also the reverse correlation with the neutral identification (-.33). The strongest relationship of satisfaction towards the organisation was registered with the strength of organisational identification (-.62). These findings indicates the need for further exploration of the role of OIS and AID, along with OIDI and IOD in predicting satisfaction towards the organisation in order to obtain directions for action targeting the improving of the level of satisfaction and identification of the teaching staff.

As we assumed in the theoretical decision of evaluating in the case of teaching staff the need for identification and their professional engagement, the data indicated the strongest connection to be between the level of organisational identification and the need for individual identification (.614), followed by the professional engagement (.41), wich justify the need to revisit the extended model of OID in the higher education context.

\section{Conclusions}

Despite the extensive litterature on organisational identification few studies were undercarried on higher education contexts and mostly on students or alumni indenfication with their university. Also, considering the amount of studies, the litterature carried out on more than one form of OID is surprisingly scarce. Apart from mediation or moderation models exploring detailed facets (mostly just) of OID, comprehensive models on the antecedents, forms and outcomes of OID are rarely empirically tested.

Most of the studies on higher education context offers and empirically test comprehensible theoretical models, based usually on social identity theory (Balaji et al., 2016; Myers et al., 2016) enhancing the need of what seems to be a basic necessity from the practical perspective on this context. Moreover, studies carried on higher 
education contexts propose theoretical models in which select antecedents of OID which are obviously particular in relevance comparing with the one considered relevant in non-academic contexts 'litterature. On this issue, present study`s findings revealed that Need for Identification, Organisational Identity Incongruence and Organisational Identity Strength are particularily relevant for the manner scolars do position themselves in respect to what the employer university value and stands for and also their satisfaction with the organisation in which they work.

Results are consistent with the extended model of organisational identification proposed by Kreiner and Ashforth (2004), Puusa \& Kekale (2015) enhancing the evidence that not just the external image of the university (Myers et al., 2016) but also the internal one, or its consistency (Balaji et al., 2016) impacts the employees identification. The significant relation registered by the strength of organisational identification (negative), ambivalent identification (negative), organisational identification (positive) with the employees' satisfaction towards the organisation is also consistent with Wilkins et al. (2016) findings on student's satisfaction with the university and OID, Liu et al. (2016) who brought evidence that OID partially mediates satisfaction or Yuan et al. (2016) who found that on low OID the impact of organisational justice on satisfaction is significant. These findings teoretically enhance the need to further explore the predictive role of organisational strenghts or organisational incongruence over employees satisfaction with their organisation in the case of academic staff.

The role registered by AID in the context of academics and the strong(est) connection registered by AID to the level of perceived organisational incongruence enhance the necessity to acknowledge the natural state of facts in the higher education context given the antagonistic requirements and constraints that universities have to face, their employee`s individuality and autonomy and gives enough reason to revisit the extended model of identification and the importance in acknowledging the existence of this form of positioning in the case of universities. From the managerial perspective AID and the strong relationship with the organisational incongruence will be the main future concern - i.e. further explore and establish the nature of the incongruent aspects and improving these elements. 
The scores recorded by the AID against the background of the other two forms of identification, at the level of the entire investigated personnel underlines the incipient presence of this representation in the case of the majority of employees; however, nowadays the organisational identification is dominant. However, we obtained the first directions for action targeting the improving of the level of satisfaction and identification of the teaching staff, namely reducing the perceived level of organisational incongruence, increasing the force or strength of BBU's identity as an organisation and reducing, as a consequence, the ambivalent identity.

The perceived differences between what the organisation stands and what the department believe, value and stands for confirmed the conclusions of Puusa \& Kekale (2015, p. 432) which stressed out "how slow and difficult it is to introduce major changes at the practical level, and that psychological realities at the departmental and organisational levels tend to be different".

Also, under the reserve of the reduced number of academics included in the study who declared that they teach mainly within the German line of study, special attention is due to the values recorded by the neutral identification, higher than in the case of all the other analysed sub-populations, because, while on the ambivalent identification one can act by transmitting at the level of the organisation a more coherent and more congruent image about the elements that are important for the organisation, in the case of neutral identification the institutional levers that can determine an improvement of the identification feeling are very reduced.

Although we have built on Lockwood et al. (2002)'s ideea that especially the Eastern societies (more collectivist) tend to manifest stronger and more independent self-constructs, focusing on themselves as part of a network of interpersonal relationships (Heine et al 1999) and thus, their members are more motivated to adapt to a group and to maintain social harmony, tending to focus on tasks and responsibilities towards others and to avoid behaviours leading to disruptions or to disappointing of significant people (Markus \& Kitayama; 1991 Triandis 1989; Lockwood et al. 2002) the correlations the promoting organisational success/ preventing organisational failure (Lockwood et al. 2002) values registered with the assessed variables were modest. 


\section{References}

Abrams, D., \& Randsley de Moura, G. (2001). “Organizational identification: Psychological anchorage and turnover". In Hogg, M.A., \& Terry, D.J. (Eds.), Social Identity Processes in Organizational Contexts (131-148). Philadelphia, UK: Psychology Press.

Abrams, D., Ando, K., \& Hinkle, S. (1998). "Psychological Attachment to the Group: Cross-Cultural Differences in Organizational Identification and Subjective Norms as Predictors of Workers' Turnover Intentions". Personality and Social Psychology Bulletin, 24(10), 1027-1039. https://doi.org/10.1177/01461672982410001.

Akdoğan, A.A., Arslan, A., \& Demirtaş, Ö. (2016). "A Strategic Influence of Corporate Social Responsibility on Meaningful Work and Organizational Identification, via Perceptions of Ethical Leadership". Procedia - Social and Behavioral Sciences, 235(2016), 259-268. https://doi.org/10.1016/j.sbspro.2016.11.029.

Allen, J.A., Crowe, J., Baran, B.E., \& Scott, C. (2016). “Organizational Identification: A Context-Specific Mitigating Resource of WorkFamily Conflict". Journal of Contingencies and Crisis Management, 24(1), 27-35. doi:10.1111/1468-5973.12102.

Amabile, T.M., Conti, R., Coon, H., Lazenby, J., \& Herron, M. (1996). "Assessing the work environment for creativity". Academy of Management Journal, 39(5), 1154-1184. doi: 10.2307/256995.

Asadullah, M.A., Akram, A., Imran, H., \& Arain, G.A. (2016). "When and which employees feel obliged: A personality perspective of how organizational identification develops." Revista de Psicología del Trabajo y de las Organizaciones, 33(2), 125-135. https://doi.org/10.1016/j.rpto.2017.02.002.

Ashforth, B.E. (2001). Role Transitions in Organizational Life: An Identity-based Perspective. New York, NY: Organization and Management Series, Routledge. 
80• Journal of Research in Higher Education • Vol. I, No. 1, 2017

Ashforth, B.E., \& Mael, F. (1989). "Social Identity Theory and the Organization". The Academy of Management Review, 14(1), 20-39. http://www.jstor.org/stable/258189.

Ashforth, B.E., Harrison, S.H., \& Corley, K.G. (2008). "Identification in Organizations: An Examination of Four Fundamental Questions". Journal of Management, 34(3), 325-374. https://doi.org/10.1177/0149206308316059.

Bagraim, J.J. (2003). "The dimensionality of professional commitment". SA Journal of Industrial Psychology, 29(2), 6-9. doi:10.4102/sajip.v29i2.104.

Balaji, M.S., Roy, S.K., \& Sadeque, S. (2016). "Antecedents and consequences of university brand identification". Journal of Business Research, 69(8), 3023-3032. https://doi.org/10.1016/j.jbusres.2016.01.017.

Bamber, E.M., \& Iyer, V.M. (2002). "Big 5 Auditors' Professional and Organizational Identification: Consistency or Conflict?". AUDITING: A Journal of Practice \& Theory, 21(2), 21-38. https://doi.org/10.2308/aud.2002.21.2.21.

Bao, G., Xu, B., \& Zang, Z. (2016). “Employees' trust and their knowledge sharing and integration: the mediating roles of organizational identification and organization-based self-esteem". Knowledge Management Research \& Practice, 14(3), 362-375. https://doi.org/10.1057/kmrp.2015.1.

Bartel, C.A. (2001). "Social Comparisons in Boundary-Spanning Work: Effects of Community Outreach on Members' Organizational Identity and Identification". Administrative Science Quarterly, 46(3), 379-413. http://www.jstor.org/stable/3094869.

Bergmann, A., Schmidt, S.L., Schreyer, D., \& Torgler, B. (2016). "Age and organizational identification: empirical findings from professional sports". Applied Economics Letters, 23(10), 718-722. http://dx.doi.org/10.1080/13504851.2015.1102837.

Bhattacharya, C.B., Rao, H., \& Glynn, M.A. (1995). "Understanding the Bond of Identification: An Investigation of Its Correlates among Art Museum Members". Journal of Marketing, 59(4), 46-57. http://www.jstor.org/stable/1252327.

Blau, G. (1989). "Testing the generalizability of a career commitment measure and its impact on employee turnover". Journal of 
Vocational

Behavior,

$35(1)$

88-103.

https://doi.org/10.1016/0001-8791(89)90050-X.

Callea, A., Urbini, F., \& Chirumbolo, A. (2016). "The mediating role of organizational identification in the relationship between qualitative job insecurity, OCB and job performance". Journal of Management Development, 35(6), 735-746. https://doi.org/10.1108/JMD-10-2015-0143.

Carlin, L., End, C.M., \& Mullins, M.E. (2010). "Validating Kreiner and Ashworth's Organizational Identification Measure in an Engineering Context". Applied HRM Research, 12(1), 75-83. http://www.xavier.edu/appliedhrmresearch/2010Winter/Article_5_End_Validating\%20Kreiner.pdf.

Caza, B.B., \& Creary, S.J. (2016). The construction of professional identity[Electronic version]. Retrieved [2017, June], from Cornell University, SHA School site: http://scholarship.sha.cornell.edu/articles/878.

Chen, M., Chen, C.C., \& Sheldon, O.J. (2016). "Relaxing Moral Reasoning to Win: How Organizational Identification Relates to Unethical Pro-Organizational Behavior". Journal of Applied Psychology, 101(8), 1082-1096. doi: 10.1037/apl0000111.

Chughtai, A.A. (2016). "Servant Leadership and Follower Outcomes: Mediating Effects of Organizational Identification and Psychological Safety". The Journal of Psychology, 150(7), 866-880. http://dx.doi.org/10.1080/00223980.2016.1170657.

Cole, M.S., \& Bruch, H. (2006). "Organizational identity strength, identification, and commitment and their relationships to turnover intention: does organizational hierarchy matter?". Journal of Organizational Behavior, 27(5), 585-605. doi:10.1002/job.378.

Commeiras, N., Loubes, A., \& Bories-Azeau, I. (2013). "Identification of organizational socialization tactics: The case of sales and marketing trainees in higher education". European Management Journal, $31(2)$ 164-178. https://doi.org/10.1016/j.emj.2012.05.002.

Conroy, S., Henle, C.A., Shore, L., \& Stelman, S. (2017). "Where there is light, there is dark: A review of the detrimental outcomes of high organizational identification". Journal of Organizational Behavior, 38(2), 184-203. doi:10.1002/job.2164. 
De Roeck, K., El Akremi, A., \& Swaen, V. (2016). “Consistency Matters! How and When Does Corporate Social Responsibility Affect Employees' Organizational Identification?". Journal of Management Studies, 53(7), 1141-1168. doi:10.1111/joms.12216.

de Souza Costa Neves Cavazotte, F., de Araujo, F.F., \& de Abreu, A.L. (2017). "Organizational identification among Brazilian public employees: a study of the cultural sector". Revista Brasileira de Gestão de Negócios, 19(64), 289-306. http://dx.doi.org/10.7819/rbgn.v19i64.3366.

Edwards, M.R., \& Peccei, R. (2010). "Perceived Organizational Support, Organizational Identification, and Employee Outcomes". Journal of Personnel Psychology, 9(1), 17-26. https://doi.org/10.1027/1866-5888/a000007.

Eisenberger, R., Armeli, S., Rexwinkel, B., Lynch, P.D., \& Rhoades, L. (2001). "Reciprocation of perceived organizational support". Journal of Applied Psychology, 86(1), 42-51. http://content.apa.org/doi/10.1037/0021-9010.86.1.42.

Erkutlu, H., \& Chafra, J. (2016). "Impact of behavioral integrity on organizational identification: The moderating roles of power distance and organizational politics". Management Research Review, 39(6), 672-691. https://doi.org/10.1108/MRR-01-20150011.

Fallatah, F., Laschinger, H.K.S., \& Read, E.A. (2017). "The effects of authentic leadership, organizational identification, and occupational coping self-efficacy on new graduate nurses' job turnover intentions in Canada". Nursing Outlook, 65(2), 172-183. https://doi.org/10.1016/j.outlook.2016.11.020.

Farooq, O., Rupp, D.E., \& Farooq, M. (2017). "The Multiple Pathways through which Internal and External Corporate Social Responsibility Influence Organizational Identification and Multifoci Outcomes: The Moderating Role of Cultural and Social Orientations". Academy of Manegement Journal, 60(3), 954-985. doi:10.5465/amj.2014.0849.

Ferris, L.J., Jetten, J., Johnstone, M., Girdham, E., Parsell, C., \& Walter, Z.C. (2016). "The Florence Nightingale Effect: Organizational Identification Explains the Peculiar Link Between Others' Suffering and Workplace Functioning in the Homelessness 
Sector". Frontiers in Psychology, 7:16. doi: 10.3389/fpsyg.2016.00016.

Gkorezis, P., \& Petridou, E. (2017). “Corporate social responsibility and pro-environmental behaviour: organisational identification as a mediator". European Journal of International Management, 11(1), 1-18. doi:10.1504/EJIM.2017.081248.

Gkorezis, P., Panagiotou, M., \& Theodorou, M. (2016). "Workplace ostracism and employee silence in nursing: the mediating role of organizational identification". Journal of Advanced Nursing, 72(10), 2381-2388. doi:10.1111/jan.12992.

Glynn, M.A. (1998). "Individuals' Need for Organisational Identification (nOID): Speculations on Individual Differences in the Propensity to Identify". In Whetten, D.A., \& Godfrey, P.C. (Eds.), Identity Organizations: Building Theory Through Conversations (238-244). Thousand Oaks, CA: Sage.

Gupta, M. (2017). “Corporate Social Responsibility, Employee-Company Identification, and Organizational Commitment: Mediation by Employee Engagement". Current Psychology, 36(1), 101-109. doi:10.1007/s12144-015-9389-8.

Hameed, I., Riaz, Z., Arain, G.A., \& Farooq, O. (2016). "How Do Internal and External CSR Affect Employees' Organizational Identification? A Perspective from the Group Engagement Model". Frontiers in Psychology, 7:788. doi:10.3389/fpsyg.2016.00788.

Haslam, S.A. (2004). Psychology in organizations: The social identity approach. London, UK: Sage.

He, H., \& Brown, A.D. (2013). “Organizational identity and organizational identification:A review of the literature and suggestions for future research". Group \& Organization Management, 38(1), 3-35. https://doi.org/10.1177/1059601112473815.

Hekman, D.R., Steensma, H.K., Bigley, G.A., \& Hereford, J.F. (2009). "Effects of organizational and professional identification on the relationship between administrators' social influence and professional employees' adoption of new work behavior". Journal of Applied Psychology, 94(5), 1325-1335. doi:10.1037/a0015315. Hekman, D.R., van Knippenberg, D., \& Pratt, M.G. (2016). “Channeling identification: How perceived regulatory focus moderates the 
84• Journal of Research in Higher Education • Vol. I, No. 1, 2017

influence of organizational and professional identification on professional employees' diagnosis and treatment behaviors". Human Relations, 69(3), 753-780. https://doi.org/10.1177/0018726715599240.

Hirst, G., van Dick, R., \& van Knippenberg, D. (2009). "A social identity perspective on leadership and employee creativity". Journal of Organizational Behavior, 30(7), 963-982. doi:10.1002/job.600.

Homburg, C., Wieseke, J., \& Hoyer, W.D. (2009). "Social Identity and the Service-Profit Chain". Journal of Marketing, 73(2), 38-54. https://doi.org/10.1509/jmkg.73.2.38.

Hoyer, P. (2016). "Making space for ambiguity: Rethinking organizational identification from a career perspective". Scandinavian Journal of Management, 32(3), 166-177. https://doi.org/10.1016/j.scaman.2016.08.002.

Humphreys, M., \& Brown, A.D. (2002). "Narratives of Organizational Identity and Identification: A Case Study of Hegemony and Resistance". Organization Studies, 23(3), 421-447. https://doi.org/10.1177/0170840602233005.

Johnson, M.D., Morgeson, F.P., Ilgen, D.R., Meyer, C.J., \& Lloyd, J.W. (2006). "Multiple professional identities: Examining differences in identification across work-related targets". Journal of Applied Psychology, 91(2), 498-506. doi:10.1037/0021-9010.91.2.498.

Klimchak, M., Carsten, M., Morrell, D., \& MacKenzie Jr., W.I. (2016). "Employee Entitlement and Proactive Work Behaviors: The Moderating Effects of Narcissism and Organizational Identification". Journal of Leadership \& Organizational Studies, 23(4), 387-396. https://doi.org/10.1177/1548051816636790.

Kong, D.T. (2016). "The pathway to unethical pro-organizational behavior: Organizational identification as a joint function of work passion and trait mindfulness". Personality and Individual Differences, 93(2016), 86-91. https://doi.org/10.1016/j.paid.2015.08.035.

Kreiner, G.E., \& Ashforth, B.E. (2004). "Evidence toward an expanded model of organizational identification". Journal of Organizational Behavior, 25(1), 1-27. doi:10.1002/job.234.

Kumar, M., \& Jauhari, H. (2016). "Satisfaction of learning, performance, and relatedness needs at work and employees' organizational identification". International Journal of Productivity and 
Performance Management, 65(6), 760-772. https://doi.org/10.1108/IJPPM-01-2016-0006.

Kurt, I. (2016). "The Mediating Role of Cynicism on Authentic Leadership and Organizational Identification Relationship". In Bilgin, M.H., Danis, H., Demir, E., \& Can, U. (Eds.), Business Challenges in the Changing Economic Landscape - Vol. 2 (391400). Springer International Publishing Switzerland 2016 doi:10.1007/978-3-319-22593-7_28.

Lam, L.W., Liu, Y., \& Loi, R. (2016). "Looking intra-organizationally for identity cues: Whether perceived organizational support shapes employees' organizational identification". Human Relations, 69(2), 345-367. https://doi.org/10.1177/0018726715584689.

Lee, J., \& Peccei, R. (2007). "Lean production and quality commitment: A comparative study of two Korean auto firms". Personnel Review, 37(1), 5-25. https://doi.org/10.1108/00483480810839941.

Lee, J., \& Peccei, R. (2007). "Perceived organizational support and affective commitment: the mediating role of organization- based self-esteem in the context of job insecurity". Journal of Organizational Behavior, 28(6), 661-685. doi:10.1002/job.431.

Lee, K.-P., You, C.-Y., \& Bae, J.-Y. (2017). "The impact of foreign ownership and control on the organizational identification of host country managers working at MNC subsidiaries". The International Journal of Human Resource Management, 28(12), 49-71. http://dx.doi.org/10.1080/09585192.2016.1244105.

Li, R., Zang, Z.-Y., \& Tian, X.-M. (2016). "Can self-sacrificial leadership promote subordinate taking charge? The mediating role of organizational identification and the moderating role of risk aversion". Journal of Organizational Behavior, 37(5), 758-781. doi: $10.1002 /$ job.2068.

Liu, H., \& Ngo, H.-Y. (2017). "The effects of gender role orientation and career/family role salience on organizational identification and intention to leave". Gender in Management: An International Journal, 32(2), 111-127. https://doi.org/10.1108/GM-03-20160027.

Liu, S., Ye, L., \& Guo, M. (2016, July 24-27). "High-performance work systems and job satisfaction: Mediation role of organizational identification". Logistics, Informatics and Service Sciences (LISS), 
86• Journal of Research in Higher Education • Vol. I, No. 1, 2017

2016 International Conference on. Retrieved from https://doi.org/10.1109/LISS.2016.7854378.

Liu, W., Zhang, P., Liao, J., Hao, P., \& Mao, J. (2016). "Abusive supervision and employee creativity The mediating role of psychological safety and organizational identification". Management Decision, 54(1), 130-147. https://doi.org/10.1108/MD-09-2013-0443.

Lockwood, P., Marshall, T.C., \& Sadler, P. (2005). "Promoting Success or Preventing Failure: Cultural Differences in Motivation by Positive and Negative Role Models". Personality and Social Psychology Bulletin, 31(3), 379-384. doi:10.1177/0146167204271598.

Lu, C.-J., Shih, Y.-Y., \& Wang, S.-T. (2016, July 6-8). "The Effect of Corporate Social Responsibility Initiatives on Internal Employee Motivation and Organizational Identification". Innovative Mobile and Internet Services in Ubiquitous Computing (IMIS), 2016 International Conference on. Retrieved from https://doi.org/10.1109/IMIS.2016.85.

Lu, V.N., Capezio, A., Restubog, S.L.D., Garcia, P.R.J.M., \& Wang, L. (2016). "In pursuit of service excellence: Investigating the role of psychological contracts and organizational identification of frontline hotel employees". Tourism Management, 56(2016), 819. https://doi.org/10.1016/j.tourman.2016.03.020.

Ma, B., Liu, S., Liu, D., \& Wang, H. (2016). "Job security and work performance in Chinese employees: The mediating role of organisational identification". International Journal of Psychology, 51(2), 123-129. doi:10.1002/ijop.12137.

Madjar, N., Greenberg, E., \& Chen, Z. (2011). "Factors for radical creativity, incremental creativity, and routine, noncreative performance". Journal of Applied Psychology, 96(4), 730-743. http://dx.doi.org/10.1037/a0022416.

Markus, H.R., \& Kitayama, S. (1991). "Culture and the Self: Implications for Cognition, Emotion, and Motivation". Psychological Review, 98(2), 224-253. doi:10.1037/0033-295X.98.2.224.

Monzani, L., Braun, S., \& van Dick, R. (2016). "It takes two to tango: The interactive effect of authentic leadership and organizational identification on employee silence intentions". German Journal of Human Resource Management: Zeitschrift für Personalforschung, 30(3-4), 246-266. https://doi.org/10.1177/2397002216649896 
Myers, K.K., Davis, C.W., Schreuder, E.R., \& Seibold, D.R. (2016). "Organizational Identification: A Mixed Methods Study Exploring Students' Relationship with Their University". Communication Quarterly, 64(2),

210-231. doi:10.1080/01463373.2015.1103285.

Newman, A., Miao, Q., Hofman, P.S., \& Zhu, C.J. (2016). “The impact of socially responsible human resource management on employees' organizational citizenship behaviour: the mediating role of organizational identification". The International Journal of Human Resource Management, 27(4), 440-455. http://dx.doi.org/10.1080/09585192.2015.1042895.

Nguyen, B., Chang, K., Rowley, C., \& Japutra, A. (2016). “Organizational citizenship behavior, identification, psychological contract and leadership frames: The example of primary school teachers in Taiwan". Asia-Pacific Journal of Business Administration, 8(3), 260-280. https://doi.org/10.1108/APJBA-01-2016-0010.

Pate, J., Beaumont, Ph., \& Pryce, G. (2009). “Organisations and the issue of multiple identities: who loves you baby?". VINE Journal of Information and Knowledge , 39(4), 319-338. https://doi.org/10.1108/03055720911013625.

Puusa, A., \& Kekäle, J. (2015). "Feelings over facts - a university merger brings organisational identity to the forefront". Journal of Higher Education Policy and Management, 37(4), 432-446. http://dx.doi.org/10.1080/1360080X.2015.1056602.

Qureshi, J.A., Shahjehan, A., Zeb, F., \& Saifullah, K. (2011). "The effect of self-esteem and organizational identification on organizational citizenship behavior: A case of Pakistani public sector university". African Journal of Business Management, 5(9), 34483456. doi:10.5897/AJBM10.391.

Rhoades, L., \& Eisenberger, R. (2002). "Perceived organizational support: a review of the literature". Journal of Applied Psychology, 87(4), 698-714. http://dx.doi.org/10.1037/0021-9010.87.4.698.

Rhoades, L., Eisenberger, R., \& Armeli, S. (2001). "Affective commitment to the organization: the contribution of perceived organizational support". Journal of Applied Psychology, 86(5), 825-836. http://dx.doi.org/10.1037/0021-9010.86.5.825. 
88• Journal of Research in Higher Education • Vol. I, No. 1, 2017

Riketta, M. (2005). "Organizational identification: A meta-analysis". Journal of Vocational Behavior, 66(2), 358-384. https://doi.org/10.1016/j.jvb.2004.05.005.

Riketta, M., \& van Dick, R. (2005). "Foci of attachment in organizations: A meta-analytic comparison of the strength and correlates of workgroup versus organizational identification and commitment". Journal of Vocational Behavior, 67(3), 490-510. https://doi.org/10.1016/j.jvb.2004.06.001.

Rim, H., Yang, S.-U., \& Lee, J. (2016). "Strategic partnerships with nonprofits in corporate social responsibility (CSR): The mediating role of perceived altruism and organizational identification". Journal of Business Research, 69(9), 3213-3219. https://doi.org/10.1016/j.jbusres.2016.02.035.

Schuh, S.C., Van Quaquebeke, N., Göritz, A.S., Xin, K.R., De Cremer, D., \& van Dick, R. (2016). "Mixed feelings, mixed blessing? How ambivalence in organizational identification relates to employees' regulatory focus and citizenship behaviors". Human Relations, 69(12),

2224-2249. https://doi.org/10.1177/0018726716639117.

Smith, L.G.E., Gillespie, N., Callan, V.J., Fitzsimmons, T.W., \& Paulsen, N. (2017). "Injunctive and descriptive logics during newcomer socialization: The impact on organizational identification, trustworthiness, and self-efficacy". Journal of Organizational Behavior, 38(4), 487-511. doi:10.1002/job.2131.

Stenling, C., \& Fahlén, J. (2014). "Same same, but different? Exploring the organizational identities of Swedish voluntary sports: Possible implications of sports clubs' self-identification for their role as implementers of policy objectives". International Review for the Sociology of Sport, 51(7), 867-883. https://doi.org/10.1177/1012690214557103.

Sung, W., Woehler, M.L., Fagan, J.M., Grosser, T.J., Floyd, T.M., \& Labianca, G.J. (2017). "Employees' responses to an organizational merger: Intraindividual change in organizational identification, attachment, and turnover". Journal of Applied Psychology, 102(6), 910-934. doi: 10.1037/apl0000197.

Tavares, S.M., van Knippenberg, D., \& van Dick, R. (2016). "Organizational identification and "currencies of exchange": integrating social identity and social exchange perspectives". 
Journal of Applied Social Psychology, 46(1), 34-45. doi:10.1111/jasp.12329.

Triandis, H.C., Bontempo, R., Betancourt, H., Bond, M., Leung, K., Brenes, A., Georgas, J., Hui, C.H., Marin, G., Setiadi, B., Sinha, J.B.P., Verma, J., Spangenberg, J., Touzard, H. \& de Montmollin, G. (1986). "The measurement of the etic aspects of individualism and collectivism across cultures". Australian Journal of Psychology, 38(3), 257-267. doi:10.1080/00049538608259013.

Tseng, L.-M., \& Wu, J.-Y. (2017). "How can financial organizations improve employee loyalty? The effects of ethical leadership, psychological contract fulfillment and organizational identification". Leadership \& Organization Development Journal, 38(5), 679-698. https://doi.org/10.1108/LODJ-07-2015-0142.

Türen, U., Erdem, H., \& Çamoğlu, A. (2017). "The effects of perceived quality of organizationally provided meal service on employees' job performance and mediating role of organizational identification". Journal of Workplace Behavioral Health, 32(1), 4971. http://dx.doi.org/10.1080/15555240.2016.1265452.

Valsania, S.E., Moriano, J.A., \& Molero, F. (2016). Authentic leadership and intrapreneurial behavior: cross-level analysis of the mediator effect of organizational identification and empowerment. International Entrepreneurship and Management Journal, 12(1), 131-152. doi:10.1007/s11365-014-0333-4.

van Dick, R. (2003). "My Job is My Castle: Identification in Organizational Contexts". In Cooper, C.L., \& Robertson, I.T. (Eds.), International Review of Industrial and Organizational Psychology, 2004, Volume 19. Chichester, UK: John Wiley \& Sons, Ltd. doi: 10.1002/0470013311.ch6.

van Gils, S., Hogg, M.A., Van Quaquebeke, N., \& van Knippenberg, D. (2017). "When Organizational Identification Elicits Moral Decision-Making: A Matter of the Right Climate". Journal of Business Ethics, 142(1), 155-168. doi:10.1007/s10551-0152784-0.

van Knippenberg, D. (2000). "Work Motivation and Performance: A Social Identity Perspective". Applied Psychology: An International Review, 49(3), 357-371. doi:10.1111/1464-0597.00020.

van Knippenberg, D., \& van Schie, E.C.M. (2000). "Foci and correlates of organizational identification". Journal of Occupational and 
90• Journal of Research in Higher Education • Vol. I, No. 1, 2017

Organizational Psychology, 73(2), 137-147. doi:10.1348/096317900166949.

van Maanen, J., \& Barley, S.R. (1984). “Occupational Communities: Culture and Control in Organizations". In Cummings, L.L., \& Staw, B.M. (Eds.), Research in organizational behavior - Vol. 6 (287365). Greenwich, CT: JAI Press.

Vandenberg, R.J., \& Scarpello, V. (1994). "A longitudinal assessment of the determinant relationship between employee commitment to the occupation and the organization". Journal of Organizational Behavior, 15(6), 535-547. http://www.jstor.org/stable/2488311. Walumbwa, F.O., Avolio, B.J., \& Zhu, W. (2008). "How transformational leadership weaves its influence on individual job performance: The role of identification and efficacy beliefs". Personnel Psychology, 61(4), 793-825. doi:10.1111/j.17446570.2008.00131.x.

Wang, H.-J., Demerouti, E., \& Le Blanc, P.M. (2017). “Transformational leadership, adaptability, and job crafting: The moderating role of organizational identification". Journal of Vocational Behavior, 100(2017), 185-195. https://doi.org/10.1016/j.jvb.2017.03.009.

Weiseke, J., Ahearne, M., Lam, S.K., \& van Dick, R. (2008). "The Role of Leaders in Internal Marketing: A Multilevel Examination Through the Lens of Social Identity Theory". Journal of Marketing, 73(2), 123-146. https://ssrn.com/abstract=1584725.

Wilkins, S., Mohsin Butt, M., Kratochvil, D., \& Balakrishnan, M.S. (2016). "The effects of social identification and organizational identification on student commitment, achievement and satisfaction in higher education". Studies in Higher Education, 41(12),

2232-2252. http://dx.doi.org/10.1080/03075079.2015.1034258.

Wu, C.-H., Liu, J., Kwong Kwan, H., \& Lee, C. (2015). "Why and when workplace ostracism inhibits organizational citizenship behaviors: an organizational identification perspective". Journal of Applied Psychology, 101(3), 362-378. http://www.apa.org/pubs/journals/apl/.

Yuan, G., Jia, L., \& Zhao, J. (2016). “Organizational identification moderates the impact of organizational justice on job satisfaction". WORK: A Journal of Prevention, Assessment \& Rehabilitation, 54(1), 189-195. doi:10.3233/WOR-162271. 
S. Mălăescu, D. Chiribucă, A. Bogdan, S. Pavlenko, M. Petric, A. Șerban, O. TĂmaș • 91

Zavyalova, A., Pfarrer, M.D., Reger, R., \& Hubbard, T.D. (2016). "Reputation as a Benefit and a Burden? How Stakeholders' Organizational Identification Affects the Role of Reputation Following a Negative Event". Academy of Management Journal, 59(1), 253-276. doi:10.5465/amj.2013.0611. 